\title{
HUBUNGAN BREASTFEEDING DENGAN INVOLUSI UTERUS PADA IBU NIFAS 0-7 HARI DI WILAYAH KERJA PUSKESMAS TANJUNGANOM KABUPATEN NGANJUK TAHUN 2017
}

\author{
Eka Deviany Widyawaty, Andini Eko Yuniarti \\ Akademi Kebidanan Wiyata Mitra Husada Nganjuk \\ Email: ekadeviany49@gmail.com
}

\begin{abstract}
ABSTRAK
Breastfeeding atau menyusui sangat penting bagi kesehatan ibu, hal ini akan mempengaruhi proses involusi rahim. Kurangnya frekuensi breastfeeding menjadi salah satu penyebab perdarahan post partum karena dengan breastfeeding dapat merangsang hormon oksitosin sehingga kontraksi rahim bisa bekerja optimal dan rahim bisa kembali seperti sebelum hamil. Tujuan dari penelitian ini adalah untuk menganalisis hubungan breastfeeding dengan involusi uterus pada ibu post partum 0-7 hari di Puskesmas Tanjunganom Kabupaten Nganjuk tahun 2017.

Jenis penelitian ini adalah penelitian analitik dengan desain cross sectional. Populasi adalah ibu post partum 0-7 hari di Puskesmas Tanjunganom Kabupaten Nganjuk tahun 2017. Sampling dilakukan dengan teknik cluster sampling sebanyak 33 responden. Pengumpulan data menggunakan lembar observasi. Variabel bebasnya adalah breastfeeding, sedangkan variabel terikatnya adalah involusi uterus pada ibu post partum 0-7 hari. Analisa data menggunakan uji ChiSquare dengan taraf signifikan $a=0,05$.

Hasil penelitian menunjukkan bahwa ibu post partum 0-7 hari yang menyusui sejumlah 25 responden $(75,8 \%)$ dan yang tidak menyusui sejumlah 8 responden $(24,4 \%)$. Ibu post partum dengan involusi uteri sesuai sejumlah 27 responden $(81,8 \%)$, sedangkan ibu post partum dengan involusi uteri tidak sesuai sejumlah 6 responden (18,2\%). Dari hasil analisis menggunakan uji ChiSquare diperoleh hasil $p$ - value $=0,001$, dengan $a=0,05$.

Berdasarkan hasil penelitian dapat disimpulkan bahwa ada pengaruh breastfeeding dengan involusi uteri. Diharapkan ibu post partum selalu menjaga kesehatan dengan melakukan kontrol ulang pada petugas kesehatan, dan lebih aktif dalam mencari informasi kesehatan terutama mengenai pentingnya menyusui.
\end{abstract}

Kata kunci: breastfeeding, Involusi uteri, postpartum,

\section{PENDAHULUAN}

\section{Latar Belakang}

Rekomendasi WHO/UNICEF pada pertemuan tahuan 1979 di Geneva tentang makanan bayi dan anak, yaitu breastfeeding merupakan bagian terpadu dari proses reproduksi yang memberikan makanan bayi secara ideal dan alamiah serta memberikan dasar biologik dan psikologik yang dibutuhkan untuk pertumbuhan. Memberi susu formula sebagai tambahan dengan alasan apapun pada bayi baru lahir harus dihindarkan (Saleha, 2009).

Involusi atau pengerutan uterus merupakan suatu proses dimana uterus kembali ke kondisi sebelum hamil dengan berat sekitar 60 gram. Proses ini dimulai segera setelah plasenta lahir akibat kontraksi otot-otot polos uterus (Ambarwati, 2010).

Bila uterus tidak mengalami atau terjadi kegagalan dalam proses involusi disebut 
dengan subinvolusi. Subinvolusi dapat disebabkan oleh infeksi dan tertinggalnya sisa plasenta/perdarahan lanjut (Ambarwati, 2010). Beberapa faktor yang dapat mencegah kejadian subinvolusi yaitu dengan cara breastfeeding.

Menurut Riskesdas 2013, proses mulai breastfeeding terbanyak terjadi pada 1-6 jam setelah kelahiran $(35,2 \%)$, sedangkan proses mulai breastfeeding terendah terjadi pada 723 jam setelah kelahiran yaitu sebesar 3,7\% (Anonim, 2015).

Berdasarkan data provinsi Jawa Timur ibu nifas 0-7 hari yang melakukan breastfeeding pada tahun 2015 menjadi $74,1 \%$ telah mencapai target (Anonim, 2015).

Berdasarkan laporan yang ada di

Dinas Kesehatan kabupaten Nganjuk tahun 2016 jumlah ibu nifas 0-7 hari yang breastfeeding di Kabupaten Nganjuk sebesar 83,34 \% (Anonim, 2015).

Berdasarkan studi pendahuluan yang dilakukan di wilayah kerja Puskesmas Tanjunganom Kecamatan Tanjunganom Kabupaten Nganjuk pada tanggal 14 Januari 2017 secara wawancara jumlah ibu nifas 0-7 hari sebanyak 10 orang diantaranya 7 ibu nifas 0-7 hari melakukan breastfeeding dan 3 orang tidak melakukan breastfeeding.

Fenomena di lapangan, masih banyak ditemukan ibu nifas pada hari ketiga dengan TFU masih satu jari dibawah pusat, padahal seharusnya sudah dua jari dibawah pusat. Hal ini menunjukkan masih banyak ibu nifas yang mengalami keterlambatan penurunan TFU (Ikhtiarinawati, 2012).
Breastfeeding dapat menghentikan pendarahan setelah melahirkan dengan merangsang timbulnya kontraksi uterus, karena pada waktu bayi menghisap puting susu ibu terjadi rangsangan ke hipofisis posterior sehingga dapat dikeluarkan oksitosin yang berfungsi untuk meningkatkan kontraksi otot polos di sekitar alveoli kelenjar air susu ibu (ASI) sehingga ASI dapat dikeluarkan dan terjadi rangsangan pada otot polos rahim sehingga rahim akan cepat kembali seperti semula (Sulistyawati, 2009).

\section{Tujuan Penelitian}

Untuk mengetahui hubungan breastfeeding dengan involusi uterus pada ibu nifas 0-7 hari di Wilayah Kerja Puskesmas Tanjunganom Kabupaten Nganjuk Tahun 2017.

\section{METODE PENELITIAN}

Penelitian ini peneliti menggunakan jenis penelitian analitik korelasi, yang bertujuan untuk menganalisis hubungan breastfeeding dengan involusi uterus pada ibu nifas 0-7 hari, dengan desain penelitian cross sectional. Populasi dalam penelitian ini adalah semua ibu nifas 0-7 hari di wilayah kerja Puskesmas Tanjunganom Kabupaten Nganjuk tahun 2017 yang berjumlah 79 orang dengan menggunakan metode cluster sampling. Setelah data terkumpul melalui lembar observasi, kemudian data dianalisis dengan menggunakan Chi Square. 


\section{HASIL PENELITIAN}

Tabel 1. Distribusi Frekuensi Ibu Nifas 0-7 Hari Berdasarkan Breastfeeding di Wilayah Kerja Puskesmas Tanjunganom Kabupaten Nganjuk Tahun 2017

\begin{tabular}{cccc}
\hline No & Breastfeeding & Jumlah & Persentase \\
\hline 1. & $\begin{array}{c}\text { Tidak } \\
\text { Melakukan }\end{array}$ & 8 & $24,2 \%$ \\
\hline 2. & Melakukan & 25 & $75,8 \%$ \\
\hline & Total & $\mathbf{3 3}$ & $\mathbf{1 0 0 \%}$
\end{tabular}

Sumber : Data Primer Penelitian, 2017

Berdasarkan tabel diatas didapatkan bahwa sebagian kecil responden tidak melakukan breastfeeding sebanyak 8 responden $(24,2 \%)$, sedangkan sebagian besar melakukan breastfeeding sebanyak 25 responden $(75,8 \%)$.

Tabel 2. Distribusi Frekuensi lbu Nifas 0-7 Hari Berdasarkan Involusi Uterus di Wilayah Kerja Puskesmas Tanjunganom Kabupaten Nganjuk Tahun 2017

\begin{tabular}{cccc}
\hline No & $\begin{array}{c}\text { Involusi } \\
\text { Uterus }\end{array}$ & Jumlah & Persentase \\
\hline 1. & $\begin{array}{c}\text { Tidak } \\
\text { Sesuai }\end{array}$ & 6 & $18,2 \%$ \\
\hline 2. & Sesuai & 27 & $81,8 \%$ \\
\hline & Total & $\mathbf{3 3}$ & $\mathbf{1 0 0 \%}$
\end{tabular}

Sumber : Data Primer Penelitian, 2017

Berdasarkan tabel 2 diketahui bahwa responden yang involusi uterus tidak sesuai sebanyak 6 responden (18,2\%), dan sebagian besar involusi uterus sesuai sebanyak 27 responden $(81,8 \%)$.

Tabel 3. Tabulasi Silang Hubungan Breastfeeding dengan Involusi Uterus pada lbu Nifas 0-7 Hari di Wilayah Kerja Puskesmas Tanjunganom Kabupaten Nganjuk Tahun 2017

\begin{tabular}{ccccc}
\hline \multirow{2}{*}{ No } & \multirow{2}{*}{ Breastfeeding } & \multicolumn{2}{c}{ Involusi Uterus } & \multirow{2}{*}{ Total } \\
\cline { 3 - 4 } & & $\begin{array}{c}\text { Tidak } \\
\text { Sesuai }\end{array}$ & Sesuai & \\
\hline \multirow{2}{*}{ 1. } & Tidak & 5 & 3 & 8 \\
& Melakukan & $15,2 \%$ & $9,1 \%$ & $24,2 \%$ \\
\hline \multirow{2}{*}{2.} & Melakukan & 1 & 24 & 25 \\
& & $3,0 \%$ & $72,7 \%$ & $75,8 \%$ \\
\hline & \multirow{2}{*}{ Total } & $\mathbf{6}$ & $\mathbf{2 7}$ & $\mathbf{3 3}$ \\
& & $\mathbf{1 8 , 2 \%}$ & $\mathbf{8 1 , 8 \%}$ & $\mathbf{1 0 0 \%}$ \\
\hline
\end{tabular}

Sumber : Data Primer Penelitian, 2017

Berdasarkan tabel di atas responden yang tidak melakukan breastfeeding dan involusi uterus tidak sesuai sebanyak 5 responden $(15,2 \%)$ serta responden yang tidak melakukan breastfeeding dan involusi uterus sesuai sebanyak 3 responden $(9,1 \%)$. Sedangkan responden yang melakukan breastfeeding dan involusi uterus sesuai sebanyak 24 responden $(72,7 \%)$ serta responden yang melakukan breastfeeding dan involusi uterus tidak sesuai sebanyak 1 responden (3,0\%). Dari data tersebut diketahui bahwa sebagian besar responden yang melakukan breastfeeding dan involusi uterus sesuai yaitu sebanyak 24 responden $(72,7 \%)$.

Berdasarkan data yang telah ditabulasi dan diolah menggunakan uji statistik Chi Square dengan taraf signifikan $\alpha=0,05$ didapatkan hasil $p$ value $=0,001$ maka $p$ value $\leq \mathrm{a}(0,05)$ maka $\mathrm{H}_{0}$ di tolak, dan dapat diambil kesimpulan bahwa ada hubungan antara breastfeeding dengan involusi uterus pada ibu nifas 0-7 hari di Wilayah Kerja Puskesmas Tanjunganom Kabupaten Nganjuk tahun 2017. 


\section{PEMBAHASAN}

Sebagian responden yang tidak melakukan breastfeeding sebanyak 8 responden (24,2\%), sebagian besar responden melakukan breastfeeding sebanyak sebanyak 25 responden (75,8\%).

Pada periode setelah persalinan terdapat perubahan-perubahan yang secara fisiologis terjadi didalam tubuh ibu dimana salah satunya organ yang mengalami perubahan itu adalah involusi, lochea, dan laktasi. Dalam involusi ini melibatkan otot-otot rahim, desidua, dan ligamentum. Segera setelah bayi lahir, uterus berkontraksi menjadi keras sehingga dapat menutup pembuluh darah besar yang bermuara pada bekas implantasi plasenta (Syelvi, 2015).

Proses involusi dapat berlangsung cepat atau lambat. Adapun faktor yang mempengaruhi involusi uterus, yaitu menyusui dini, status gizi, pendidikan, usia, paritas, dan mobilisasi (Cunningham, 2007).

Secara umum breastfeeding dapat menghentikan pendarahan setelah melahirkan dengan merangsang timbulnya kontraksi uterus, karena pada waktu bayi menghisap puting susu ibu terjadi rangsangan ke hipofisis posterior sehingga dapat dikeluarkan oksitosin yang berfungsi untuk meningkatkan kontraksi otot polos di sekitar alveoli kelenjar air susu ibu (ASI) sehingga ASI dapat dikeluarkan dan terjadi rangsangan pada otot polos rahim sehingga rahim akan berkontraksi dan uterus dapat kembali kebentuk sebelum hamil (Sulistyawati, 2009).
Breastfeeding dipengaruhi oleh faktor umur ibu. Pada ibu yang usianya lebih tua banyak dipengaruhi oleh proses penuaan, dimana pada proses penuaan terjadi peningkatan jumlah lemak, penurunan elastisitas otot dan penurunan penyerapan lemak, protein, serta karbohidrat. Bila proses ini dihubungkan dengan penurunan protein pada proses penuaan, maka hal ini akan menghambat involusi uterus (Abdul Bari, 2002).

lbu yang melakukan inisiasi manyusui dini akan mempercepat involusi uterus karena pengaruh hormon oksitosin ditandai dengan rasa mulas karena rahim yang berkontraksi. Menyusui merangsang pengeluaran hormon oksitosin yang akan mampu meningkatkan proses kontraksi uterus yang akhirnya memberikan dampak terhadap semakin cepatnya proses involusi uterus. Pada proses menyusui ada reflek let down dari isapan bayi yang merangsang hipofise posterior mengeluarkan hormon oxytosin yang oleh darah hormon ini diangkat menuju uterus dan membantu uterus berkontraksi sehingga proses involusi uterus terjadi (Abdul Bari, 2002).

Selain itu, hasil penelitian ini telah menemukan fakta bahwa responden yang memiliki involusi uterus tidak sesuai sebanyak 6 responden (18,2\%), dan memiliki involusi sesuai sebanyak 27 responden $(81,8 \%)$. Sebagian besar ibu nifas 0-7 hari yang mengalami involusi uterus sesuai di wilayah kerja Puskesmas Tanjunganom ini berusia antara 20-35 tahun, usia tersebut 
merupakan usia sehat untuk reproduksi. Setelah ibu melahirkan pada usia antara 2035 tahun memiliki resiko lebih rendah mengalami gangguan kesehatan pada ibu, karena wanita pada kelompok usia reproduksi sehat memiliki kematangan alat reproduksi, emosional maupun sosial sehingga mempercepat pengembalian uterus.

Analisa data yang diperoleh dari tabulasi silang didapatkan fakta bahwa ibu nifas 0-7 hari yang yang tidak melakukan breastfeeding dan mengalami involusi uterus tidak sesuai sebanyak 5 responden $(15,2 \%)$ serta responden yang tidak melakukan breastfeeding dan mengalami involusi uterus sesuai sebanyak 3 responden $(9,1 \%)$. Sedangkan responden yang melakukan breastfeeding dan mengalami involusi uterus sesuai sebanyak 24 responden $(72,7 \%)$ serta responden yang melakukan breastfeeding dan yang mengalami involusi uterus tidak sesuai sebanyak 1 responden (3,0\%). Dari data tersebut diketahui bahwa sebagian besar responden yang melakukan breastfeeding dan mengalami involusi uterus sesuai yaitu sebanyak 24 responden (72,7\%).

Peneliti berasumsi bahwa adanya hubungan antara breastfeeding dengan involusi uteri, karena apabila ibu melakukan inisiasi menyusu dini akan mempercepat involusi uterus karena pengaruh hormon oksitosin ditandai dengan rasa mulas karena rahim yang berkontraksi.
Dari uji Chi Square didapatkan hasil pvalue $\leq \mathrm{a}(0,05)$ dan $\mathrm{p}$-value $=0,001$, dimana $0,001 \leq 0,05$ yang berarti $\mathrm{H}_{0}$ ditolak yang artinya ada hubungan antara breastfeeding dengan involusi uterus pada ibu nifas 0-7 hari di wilayah kerja Puskesmas Tanjunganom Kabupaten Nganjuk tahun 2017.

\section{KESIMPULAN}

Berdasarkan hasil analisis dan pembahasan pada bab sebelumnya, maka peneliti dapat menyimpulkan: Breastfeeding di wilayah kerja Puskesmas Tanjunganom Kabupaten Nganjuk tahun 2017 sebagian besar tergolong melakukan yaitu sebanyak 25 responden (75,8\%). Involusi uterus pada ibu nifas 0-7 hari di wilayah kerja Puskesmas Tanjunganom Kabupaten Nganjuk tahun 2017 sebagian besar tergolong involusi uterus sesuai yaitu sebanyak 27 responden $(81,8 \%)$. Hasil uji Chi Square didapatkan hasil ada hubungan antara breastfeeding dengan involusi uterus pada ibu nifas 0-7 hari di wilayah kerja Puskesmas Tanjunganom Kabupaten Nganjuk tahun 2017.

\section{SARAN}

Diharapkan ibu post partum selalu menjaga kesehatan dengan melakukan kontrol ulang pada petugas kesehatan, dan lebih aktif dalam mencari informasi kesehatan terutama mengenai pentingnya menyusui 


\section{DAFTAR PUSTAKA}

Ambarwati. 2010. Asuhan Kebidanan Nifas.

Yogyakarta : Pustaka Prima.

Abdul Bari, S. 2002. Buku Panduan Praktis Pelayanan dan Kesehatan Maternal dan Neonatal. Jakarta : YBPSP.

Cunningham. 2013. Obstetri Williams. Jakarta : EGC.

Ikhtiarinawati, F. 2012. Perbedaan Penurunan Tinggi Fundus Uteri Berdasarkan Jenis Persalinan pada Ibu Nifas Fisiologis dan Post Sectio Caesarea. Jurnal Midpro edisi 2.

Profil Kesehatan Indonesia. 2015. Kemenkes RI. Jakarta.

Profil Kesehatan Kabupaten Nganjuk. 2015. Dinkes Kabupaten Nganjuk.

Saleha, S. 2009. Asuhan Kebidanan pada Masa Nifas. Jakarta : Salemba Medika.

Sulistyawati, A. 2009. Buku Ajar Asuhan Kebidanan pada lbu Nifas. Yogyakarta: Andi.

Syelvi. 2015. Hubungan Inisiasi Menyusu Dini dengan Involusi Uterus lbu Post Partum Normal Hari Ke 7. Jurnal IImu Kesehatan 'Afiyah Volume 3 No. 1. 